\title{
Evaluating Sexual Satisfaction and Quality of Life in Patients with Gynecological Cancer
}

\section{Jinekolojik Kanserli Hastalarda Cinsel Doyum ve Yaşam Kalitesinin Değerlendirilmesi}

\author{
Yaşar Yıldız ${ }^{1}$, Ahmet Alacacıoğlu' ${ }^{1}$, Umut Varol ${ }^{1}$, Yüksel Küçükzeybek ${ }^{1}$, Nuri Aşık1, Tarık Salman ${ }^{1}$, \\ Halil Taşkaynatan ${ }^{1}$, Utku Oflazoglu ${ }^{1}$, Murat Akyol ${ }^{1}$, Mustafa Oktay Tarhan² \\ ${ }^{1}$ Department Of Medical Oncology, Izmir Katip Celebi University Ataturk Training And Research Hospital, \\ Izmir, Turkey \\ ${ }^{2}$ Institute of Oncology, Dokuz Eylul University, Izmir, Turkey
}

Dergiye Ulaşma Tarihi:23.03.2018 Dergiye Kabul Tarihi:30.05.2018 Doi: 10.5505/aot.2018.04834

\section{ÖZET}

GİRIŞ ve AMAÇ: Jinekolojik kanser tedavileri, hastaların psikoseksüel durumlarını ve yaşam kalitelerini etkileyebilir. $\mathrm{Bu}$ çalışmamızın amacı jinekolojik kanserli (JK) hastalarda cinsel doyum durumlarını değerlendirmektir. Ayrıca cinsel doyum durumları ile birlikte psikolojik durumları (anksiyete ve depresyon) ve yaşam kaliteleri değerlendirildi.

YÖNTEM ve GEREÇLER: Kemoterapi alan ve izlemdeki JK'li hastalarının verileri, yüz yüze anketler yapılarak bilgiler toplanmıştır. Görüşmeler sırasında dört form kullanılmıştır. İlk form sosyo-demografik özelliklerden oluşmaktadır. Diğer formlar, Golombok-Rust Cinsel Doyum Anketini (GRISS), European Organization for Research on Treatment of Cancer Questionnaires-C30 Yaşam Kalitesi Anketini (EORTC-QoL-C30), DurumlukSürekli Kayg1 Envanteri (STAI), Beck Depresyon Envanteri (BDI) idi.

BULGULAR: Bu çalışmaya, JK'li 62 hasta dahil edildi. Toplam GRISS skoru 37.54 \pm 11.71 olup, 33 hastada (\%53) GRISS cut-off skoru > 35'e göre cinsel tatminsizlik görülmüştür. Toplam GRISS skoru düşük olan hastalar $(<35)$, total GRISS skoru $(\geq 35)$ olan hastalarla karşılaştırıldığında depresyon skorları $(p=0.010)$ ve STAI-II skorları ( $\mathrm{p}=0.044)$ anlamlı olarak yüksekti ve EORTC-QLQ-C30 yaşam kalitesi alt ölçekleri (fiziksel işlevler $(p=0.004)$, bilişsel işlevler $(p=0.021)$, duygusal işlevler $(p=0.019)$ ve global yaşam kalitesi $(p=0.022)$ anlaml olarak daha düşüktü.

TARTIŞMA ve SONUÇ: Cinsel olarak doyumsuz olan hastalar kötü yaşam kalitesine sahiptirler ve genellikle endişeli ve depresiftirler. Jinekolojik hastaların onkolojik tedavilerinin yanı sıra, cinsel rehabilitasyon ve psikolojik duygu durumlarının rutin değerlendirmelerde entegrasyonunun sağlanması gerekmektedir.

Anahtar Kelimeler: Cinsel doyum, anksiyete, depresyon, yaşam kalitesi

\begin{abstract}
INTRODUCTION: Treatments in gynecologic cancer can affect a patient's psychosexual status and quality of life. The aim of this study was to evaluate the sexual satisfaction levels in patients with gynecological cancer (GC). We also evaluated the relationship between sexual status of these patients with the psychological status (anxiety and depression) and quality of life.

METHODS: The data for GC patients treated with chemotherapy or in surveillance were collected by using four forms completed during face-to-face interviews. The first form consists of socio-demographic features. Other forms were Golombok-Rust Inventory of Sexual Satisfaction (GRISS), European Organization for Research on Treatment of Cancer Questionnaires Quality of Life-C30 (EORTC-QLQ-C30), State-Trait Anxiety Inventory (STAI), Beck Depression Inventory (BDI) scoring system.

RESULTS: In this study, 62 patients with GC were included. The mean total GRISS score was $37.54 \pm 11.71$ and sexual dissatisfaction was seen in 33 patients (53\%) according to GRISS cut-off score>35. Depression scores $(\mathrm{p}=0.010)$ and STAI-II scores $(\mathrm{p}=0.044)$ were significantly higher, and EORTC-QLQ-C30 function subcales (physical functioning $(\mathrm{p}=0.004)$, cognitive functioning $(\mathrm{p}=0.021)$, emotional functioning $(\mathrm{p}=0.019))$ and the global quality-of-life $(\mathrm{p}=0.022)$ were significantly lower in patients with high total GRISS scores $(\geq 35)$ when compared with the patients with low total GRISS scores $(<35)$.

DISCUSSION AND CONCLUSION: Patients with sexual dissatisfaction have poor quality of life, and they are generally anxious and depressive. Besides the oncological treatments of the GC patients, it is necessary to make integration of sexuality rehabilitation and physiological status into their routine assessment.

Keywords: sexual satisfaction, anxiety, depression, quality of life.
\end{abstract}




\section{INTRODUCTION}

Gynecological cancers are one of the most common cancer and a major public health problem. Gynecological cancer patients are often diagnosed at advanced stages. The 5 year survival rates are approximately $45 \%$ for ovarian cancer, $83 \%$ for uterine corpus cancer and $70 \%$ for uterine cervix cancer and the 15$20 \%$ of these cases are in women under the age of 40. (1) Standard treatment modalities may include hysterectomy, bilateral salpingooophorectomy, pelvic and para-aortic lymphadenectomy and adjuvant chemotherapy and/or pelvic radiation. All of these treatments have a detrimental effect on female reproductive potential, patient's self-esteem, quality of life and psychosexual status. (2)

The diagnosis of gynecological cancer has a devastating effect on psychological and emotional well-being for woman. Surgical treatment can result in distortions of female anatomy for patients with gynecologic cancers. Additionally, in premenopausal women the removal of the ovaries results to premature menopause with changes in hormonal and physical status that can alter several domains of sexual function (3). Chemotherapy can lead to systemic effects that dampen both sexual desire and arousal. Chemotherapy may also induce ovarian failure with an acute and sudden loss of estrogen in addition to alopecia that can affect a patient's self-perception of sexual attractiveness. Radiotherapy to the pelvis may cause vaginal or rectal mucosal toxicity (4), vaginal fibrosis or stenosis that limits a woman's capacity for vaginal intercourse as well as affects her genital pelvic and clitoral sensitivity during sexual activity. All of these may have significant impact on sexual activity from functional to emotional effects (5).

Sexuality is defined a state of physical, emotional, mental and social wellbeing; it is not merely the absence of disease, dysfunction or infirmity. Sexual satisfaction is defined as the level of happiness and pleasure of an individual's sexual relations and is determined by the sexual and non sexual aspects of the relationship. Sexuality is an integral element of human life and has been identified as an important QoL component $(6,7,8)$. There are a variety of factors that affect individual sexual satisfaction such as social relationships, general conditions, the gender, age, the cultural environment, and physical and mental health (9). As a result, sexuality are affected with a diagnosis of cancer, the treatment componential of cancer, side effects related with treatment, psychological stress following therapy and relationship with partner during treatment (6).

The most common psychological morbidities experienced by patients with cancer are depression and anxiety (10). It is known that symptoms of depression and anxiety impair quality of life. Quality of Life is a multidimensional property that may include physical, material, social and emotional wellbeing, and development and activity. Quality of life can also be affected by sexual satisfaction. This study aimed to evaluate in detail the sexual satisfaction levels of GC patients and its relationship with the psychological status (anxiety and depression) and quality of life.

\section{PATIENTS and METHODS}

\section{Patient Selection}

Sixty-two GC patients treated in Izmir Katip Celebi University Atatürk Research and Training Hospital Clinics of Medical Oncology between November 2014 and February 2016 were participated in this study. Eastern Cooperative Oncology Group (ECOG) performance status was 0-1. Patients with poor performance status $(E C O G \geq 2)$ and age 65 and older were excluded. Patients treated with radiotherapy were also excluded. The patients were informed about the study and then informed consent was applied. The 4 questionnaires used in the study were explained verbally in detail and asked to fill in the surveys were delivered to the patients who agreed to participate.

\section{Data collection}

There were four forms which were completed by the participants. The first form consisted of questions regarding the demographic characteristics of the patients. The second form was the Golombok-Rust Inventory of Sexual Satisfaction (GRISS). The GRISS is composed of 28-item questionnaire used to evaluate the presence and extend of sexual problems. It includes 7 subscales evaluating frequency, lack of communication, satisfaction, avoidance, touch, vaginismus and anorgasmia. In any category; a score of 5 points and the total scores 
35 or higher points shows sexual dysfunction and. Tugrul at al did the validation and reliability study of the GRISS in Turkish population (11). The third form was European Organization for Research on Treatment of Cancer Questionnaires Quality of Life-C30 (EORTC-QoL-C30). In this form, there are 30 items divided into three major domains that measure the quality of life of cancer patients: symptom scales, functional scales and global health/quality of life (12). Functional scales consist of physical well-being (five items), role wellbeing (two items), emotional well-being (four items), cognitive well-being(two items), social well-being (two items) and quality of life scale(two items) (12). We didn't include symptom scales (nine item) in our analysis. It is a five point Likert Scale ranging from 0 points (never) 3 to 4 points (always) for each question and high scores show higher quality of life. The fourth form was related to physiological status; Beck Depression Inventory (BDI) and StateTrait Anxiety Inventory (STAI). BDI is a series of questions designed to measure the severity, intensity and depth of depression in patients with psychiatric disorders. BDI was developed in 1961 by Beck (13). It includes 21 questions, each with 4 possible responses. Each response is assigned a score ranging from zero to three, indicating the severity of the symptom. Individual questions of the BDI evaluate mood, pessimism, guilt, punishment, sense of failure, self dissatisfaction, self-dislike, self-accusation, suicidal motions, crying, irritability, social withdrawal, body image, work difficulties, insomnia, fatigue, appetite, weight loss, bodily preoccupation, and loss of libido. Questions 1 to 13 assess symptoms that are psychological in nature, while questions 14 to 21 assess more physical symptoms (14). BDI was translated into Turkish and reliability was recalculated by Tegin and Hisli $(15,16)$. For the Turkish population, a score of 17 or over points out depression by Hisli. We used these cut-off scores to describe the levels of depression. STAI questionnaire provides a reliable measure of anxiety. STAI, originally developed by Spielberger in the 1970s, consists of two subscales: state anxiety and trait anxiety. The STAI-1 subscales (20 questions) measure the state anxiety by asking the subjects to feel "right now". The STAI-II subscales (20 questions) measure trait anxiety by asking subject show they 'generally' feel. Each response is given a score ranging from one to four indicating the symptom severity. State/trait anxiety is scored separately and scores range from 20 to 80 , high scores represent a greater level of anxiety. It has been translated and validated in Turkish language by Oner (17). The cutt-off value is 35 or over for trait anxiety.

\section{Statistical analysis}

All data were analyzed using SPSS for Windows version 20.0. Descriptive statistics summarized frequencies and percentages for categorical variables, mean and standard deviation for continuous variables. For independent samples, $\mathrm{T}$ tests were used to compare categorical variables. A value of $\mathrm{p}<$ 0.05 was considered as significant.

\section{RESULTS}

The mean age of the 62 patients was 52.88 (range: 22-65). Thirty-three (53\%) of 62 patients was been receiving chemotherapy and the others were under surveillance. Of the patients, $77 \%$ of them were primary school graduated, while only $16 \%$ were graduated from college. Most of the patients $(71 \%)$ were married. Ninety-eight percent of the patients were non-smokers and none of the patients had regular use of alcohol. Eighty-nine percent $(\mathrm{n}=$ 55) of patients had ovarian cancer, and $11 \%$ (n $=7$ ) had uterus cancer. Seventeen patients (27\%) 4 had local disease, 19 patients (31\%) had locally advanced disease and 26 patients (42\%) had relapsing/metastatic disease. Demographic and disease-related characteristics are shown in Table 1.

Forty-five patients responded to STAI-II, and 48 patients responded to the BDI questionnaire. Hisli at all has defined the depression limit point in the Beck depression scale as 17 above for the Turkish population. According to this point, $16.6 \%$ of the patients were found to be depressive. Anxiety limit point in the Trait Anxiety Inventory scale has accepted as 35 above for the Turkish population. Nearly half of the patients had anxiety (57\%) according to this cut-off value in STAI-II.

The mean scores of the GRISS subscales were shown in Table 2. The mean total GRISS score of the GC patients was $37.54 \pm 11.71$. Sexual dissatisfaction was seen in 
33 patients (53\%) according to the Turkish validation value. The accepted cut-off value of GRISS for Turkish people is 35 and accordingly, it was determined that 43 patients (69\%) had problems with communication, 54 (87\%) with frequency, 23 (37\%) with satisfaction, $40(64 \%)$ with avoidance, $42(67 \%)$ with touch, $56(90 \%)$ with vaginismus and 30 (48\%) with anorgasmia.

Depression, anxiety, quality of life and the total GRISS scores were compared and the comparison was shown in Table 3. When the GC patients' total GRISS scores and depression levels were compared we found that patients with high total GRISS scores ( $\geq 35$ ) was found to have high depression levels $(\mathrm{p}=0.010)$. Similarly, we compared the anxiety scores with the scores of total GRISS. Patients with a high total GRISS score $(\geq 35)$ were found to have high levels of trait anxiety which was statistically significant $(\mathrm{p}=0,044)$.

In addition, we compared total GRISS scores and sociodemographic characteristics. There was not any statistical significance between total GRISS scores and sociodemographic characteristics such as marital status, education status, monthly income and chemotherapy receiving or surveillance status.

Sixty-two patients answered the EORTC-QLQ-C30 questionnaire and 62 patients responded to the GRISS questionnaire. The total GRISS scores and the EORTC-QLQC30 function subcales and global QoL was compared. In patients with total GRISS scores $\geq 35$, physical functioning $(\mathrm{p}=0.004)$, cognitive functioning ( $\mathrm{p}=0.021)$, emotional functioning $(\mathrm{p}=0.019)$ and global Quality of Life $(\mathrm{p}=0,022)$ were statistically significantly low. The social functioning levels of the patients were also significant at the border $(\mathrm{p}=0,050)$. There was no statistical significance between GRISS score of patients and role functions.
Table 1. Demographic characteristics of the patients

\begin{tabular}{l|c}
\hline & Patients (n=62) \\
\hline Age (Range) & $52.88(22-65)$ \\
Marital status & \\
Single & $29 \%(18)$ \\
Married & $71 \%(44)$ \\
Education & \\
Primary Education & $77 \%(48)$ \\
High School & $16 \%(10)$ \\
University & $7 \%(4)$ \\
Smoking & \\
Yes & $2 \%(1)$ \\
No & $98 \%(61)$ \\
Receiving chemotherapy & \\
Yes & $53,2 \%(33)$ \\
No & $46,8 \%(29)$ \\
Monthly income & \\
$0-250(\$)$ & $68 \%(42)$ \\
$250(\$)$ above & $32 \%(20)$ \\
\hline
\end{tabular}

Table 2. The mean scores of GRISS, EORTC-QLQ-C30, anxiety and depression of gynecological cancer patients

\begin{tabular}{|c|c|c|c|c|c|}
\hline \multicolumn{2}{|c|}{$\begin{array}{l}\text { GRISS } \\
(\mathrm{n}=62)\end{array}$} & \multicolumn{2}{|c|}{$\begin{array}{l}\text { EORTC-Q0L-C30 } \\
\quad(\mathrm{n}=62)\end{array}$} & $\begin{array}{c}\text { BDI } \\
(\mathrm{n}=48)\end{array}$ & $\begin{array}{l}\text { STAI-II } \\
(\mathrm{n}=45)\end{array}$ \\
\hline Frequency & $6.46 \pm 1.92$ & Physical functioning & $75.27 \pm 17.42$ & $9.20 \pm 7.87$ & $39.95 \pm 11.62$ \\
\hline Communication & $6.12 \pm 3.04$ & Role functioning & $87.71 \pm 17.94$ & & \\
\hline Satisfaction & $3.80 \pm 2.18$ & Emotional functioning & $84.78 \pm 18.29$ & & \\
\hline Avoidance & $5.24 \pm 2.73$ & Cognitive functioning & $83.00 \pm 22.53$ & & \\
\hline Touch & $5.69 \pm 2.69$ & Social functioning & $83.77 \pm 19.59$ & & \\
\hline Vaginismus & $5.82 \pm 1.29$ & Global quality of life & $73.39 \pm 24.91$ & & \\
\hline Anorgasmia & $4.54 \pm 2.19$ & & & & \\
\hline Glombock total & $37.54 \pm 11.71$ & & & & \\
\hline
\end{tabular}

Table 3. Comparison of total GRISS scores with anxiety, depression and quality of life subscales

\begin{tabular}{|c|c|c|c|c|}
\hline & \multicolumn{4}{|c|}{ Total GRISS Scores } \\
\hline & $\mathrm{n}(<35 / \geq 35)$ & $<35$ & $\geq 35$ & $\mathrm{p}$ \\
\hline STAI-II & $23 / 22$ & $36.52 \pm 8.55$ & $43.54 \pm 13.41$ & 0.044 \\
\hline BDI & $25 / 23$ & $6.44 \pm 6.75$ & $12.21 \pm 8.04$ & 0.010 \\
\hline Physical functioning & $29 / 33$ & $81.75 \pm 11.94$ & $69.57 \pm 19.55$ & 0.004 \\
\hline Role functioning & $29 / 33$ & $88.94 \pm 15.89$ & $86.63 \pm 19.75$ & 0.617 \\
\hline Cognitive functioning & $29 / 33$ & $90.27 \pm 11.08$ & $79.95 \pm 21.88$ & 0.021 \\
\hline Social functioning & $29 / 33$ & $88.82 \pm 13.66$ & $79.33 \pm 22.92$ & 0.050 \\
\hline Emotional functioning & $29 / 33$ & $89.96 \pm 16.48$ & $76.89 \pm 25.45$ & 0.019 \\
\hline Global QoL & $29 / 33$ & $81.03 \pm 24.38$ & $66.67 \pm 23.73$ & 0.022 \\
\hline
\end{tabular}




\section{DISCUSSION}

Cancer disease and all these treatment paradigms may cause sexual morbidity. A healthy sexual relationship needs a balanced interaction between sexual structures and neuronal, vascular and hormonal systems and a healthy mental state (9). The experience of cancer diagnosis and its treatment may deeply affect a woman's body image and sense of sexuality (18). In addition to the direct effects of radiation on the gonads, chemotherapy and radiation alter the hormonal milieu by disrupting the hypothalamic-pituitary-gonadal axis.

Several studies were focused especially on sexual satisfaction in cancer patients. Currently, discussion of psychological problems is the main subject for sexual evaluation. Many different cancer survivors (colorectal, breast, prostate, testis cancer) can be effected by sexual problems after cancer treatment (19-22). This Golombok Rust Inventory of Sexual Satisfaction survey evaluate how women relate to their own body and to their partner's, the level of interest in sexual activity, sexual frequency, quality of communication with the partner, and the ability to achieve orgasm. The mean total GRISS score was $37.54 \pm 11.71$ and sexual dissatisfaction was seen in 33 patients $(53 \%)$ of the patients in our study. Giorno et al. also found similar mean total score for postmenopausal women (38.64 \pm 16.82$)$ (23). Chan et al. evaluated the rate of sexual satisfaction including 228 women with localized cervical cancer and 125 with localized ovarian cancer. The satisfaction with Life scale was used in this study. Sexual dissatisfaction was reported $49 \%$ of the patients surveyed in this study (24). In another study, sexual satisfaction was found to be lower (41\%) in ovarian cancer patients (25).

Sexuality has been recently recognized as an important component of Quality of life (26). The effect of sexual satisfaction on quality of life was evaluated in our study. We found that patients with a high total GRISS score had also poor quality of life scores. Studies evaluating the effect of sexual satisfaction on the quality of life in gynecological cancer patients are very limited in the literature. Levin et al. similarly found that sexual status is a significant unique predictor of the psychological QoL $(\mathrm{p}=0.011)$ in gynecological cancer patients (27). Kim at al. compared the quality of life and sexuality between sexually active ovarian cancer survivors and healthy women (28). In total, 73 ovarian cancer survivors and 73 healthy women were included. Satisfaction, sexuality, desire, orgasm, in terms of interest in sex, sexual activity and enjoyment of sex were similar between the groups (28). There was also no significant difference between the two groups in terms of EORTC QLQ-C30 subscores (28).

In our study, the mean anxiety value was $39.95 \pm 11.62$ and the mean depression value was $9.20 \pm 7.87$. We found that $57 \%$ of the patients showed results above the cut-off for anxiety and $16.6 \%$ of the patients had high depression values above the cut-off. Linden at al. (29) declared the anxiety and depression rate of patients after cancer diagnosis. In this study, for gynecological cancers the level of anxiety was $56.2 \%$ (subclinical) and $28.4 \%$ (clinical), and the levels of depression rate was $38.8 \%$ (subclinical) and 16.5 (clinical) (29). Sam et al (30) reported that the rate of depression was $25.3 \%$ and the rate of anxiety was $19.1 \%$ before the initiation of treatment in ovarian cancer patients. In the Turkish study, Evsen et al. revealed that the mean anxiety value was 43.1 \pm 9.77 for $\mathrm{GC}$ patients receiving chemotherapy (31). In another study conducted by Chittrakul et al. (32) the prevalence of anxiety was 7.1 and the prevalence of depression was 3.6 in Thai ovarian cancer patients following treatment.

The rates were very low when compared to patients with other nationalities. The rates of anxiety and depression were investigated in different types of cancer. Akyol at al reported that $44 \%$ of patients with 105 colorectal cancer had depression and $29 \%$ of patients had high anxiety (19). In another study, Alacacioglu at al. investigated the rate of depression and anxiety in the testicular cancer survivors (22) and they found $29.2 \%$ and $55.2 \%$ respectively. Depression and anxiety rates are exactly different for the patients of GC when compared to other tumors. The reason of this difference between different populations for the same cancer and also for different cancer types can be assumed that the general characteristics of these populations and patient composition are different (33).

There are studies showing that sexual dissatisfaction increases depression and anxiety

Adress for correspondence: Prof. Dr. Ahmet Alacacioğlu, Department Of Medical Oncology, Izmir Katip Celebi University Ataturk Training And Research Hospital, Izmir, Turkey 
rates. Sexual morbidity was a significant predictor for the depressive symptoms $(\mathrm{p}=$ $0.044)$ and body change stress $(p=0.008)(27)$. In another study, sexual dissatisfaction potentially caused high levels of depression and anxiety (33). As a result, gynecological cancer is a disease that may have psychosocial and psychosexual effects on patients. Thus, it is important to take precautions including psychoeducational support, group therapy, sexual counseling, marital counseling, or psychotherapy to reduce this psychosocial and psychosexual contagion of the patients, thus improving the quality of life.

Conflict of interest: The authors declare that they have no conflict of interest

\section{REFERENCES}

1. Siegel R, Miller K, Jemal A. Cancer statistics, 2015. CA Cancer J Clin [Internet] 2015;65(1):29. Available from:

http://onlinelibrary.wiley.com/doi/10.3322/caac.2125 4/pdf

2. Chan JL, Wang ET. Gynecologic Oncology Oncofertility for women with gynecologic malignancies. Gynecol Oncol [Internet] 2016;(144(3):631-6. Available from: http://dx.doi.org/10.1016/j.ygyno.2016.12.013

3. Falk SJ, Dizon DS. Sexual dysfunction in women with cancer. Fertil Steril 2013;100(4):916-21.

4. Krychman ML, Carter J, Aghajanian CA, Dizon DS, Castiel M. Chemotherapyinduced dyspareunia: a case study of vaginal mucositis and pegylated liposomal doxorubicin injection in advanced stage ovarian carcinoma. Gynecol Oncol 2004;93:561-3.

5. Katz A. The Sounds of Silence: Sexuality Information for Cancer Patients. J Clin Oncol 2017;23(1):18-21.

6. For M. sexuality: a quality-of-11fe 1 ssue for cancer survivors. Semin Oncol Nursing, 2008;24(2):71-9.

7. Bae H, Park H. Sexual function, depression, and quality of life in patients with cervical cancer. Support Care cANCER 2016;(24):1277-83.

8. Bradford A, Fellman B, Urbauer D, et al. Assessment of sexual activity and dysfunction in medically underserved women with gynecologic cancers. Gynecol Oncol 2015;139:134-40.

9. Gül IG, Kartalci Ş, Cumurcu BE, Karincaoğlu Y, Yoloğlu S, Karlidağ R. I Behçet's disease with or without depression. J Eur Acad Dermatology Venereol 2013;27(10):1244-51.

10. Massimo Pasquini*1 2 and Massimo Biondi1. Depression in cancer patients: a critical 8 review. Clin Pract Epidemiol Ment Heal 2007;12(3,2):1-10.

11. Ceylan TUĞRUL, Nedret ÖZTAN DEK. GolombokRust Cinsel Doyum Ölçeği'nin Standardizasyon Çalışması. Türk Psikiyatr Derg 1993;4:83-8.

12. Aaronson NK, Ahmedzai S, Bergman B, et al. The European Organization for Research and Treatment of cancer QLQ-C30: A Quality -of-Life Instrument for
Use in International Clinical Trials in Oncology. J Natl Cancer Inst 1993;85(5):365-76.

13. Beck at, ward ch, mendelson $m$, mock j, erbaugh j. An inventory for measuring depression. Arch Gen Psychiatry [Internet] 1961;4:561-71. Available from: http://www.ncbi.nlm.nih.gov/pubmed/13688369

14. Beck AT, Steer RA. Internal consistencies of the original and revised Beck Depression Inventory. J Clin Psychol 1984;1961:1979-81.

15. Tegin B. Cognitive disorders in depression: A review according to Beck model. Psychol J 1987;(6):116-23.

16. Hisli N. Validation of the BDI with a Group of Turkish Psychiatric Outpatients. 1988;(July):22:118-116.

17. Oner N. State/trait Anxiety inventory Bogazici University Publ Istanbul. 1998;2-26.

18. Ana Begovic-Juhant $\mathrm{PhD}$ a, Amy Chmielewski BA b SIP a \& LACM a. Impact of body image on depression and quality of life among women with breast cancer. 2012;446-60.

19. Akyol M, Ulger E, Alacacioglu A, et al. Sexual satisfaction, anxiety, depression and quality of life among Turkish colorectal cancer patients [Izmir Oncology Group (IZOG) study]. Jpn J Clin Oncol [Internet] 2015;45(7):657-64.

20. Can H. Depression, Anxiety and Sexual Satisfaction in Breast Cancer Patients and their Partners-Izmir Oncology Group Study. Asian Pac J Cancer Prev 2014;(15(24)):10631-6.

21. Gilbert SM, Dunn RL, Wittmann D, et al. Quality of life and satisfaction among prostate cancer patients followed in a dedicated survivorship clinic. Cancer 2015;121(9):1484-91.

22. Alacacioglu A, Ulger E, Varol U, et al. Sexual satisfaction, anxiety, depression and quality of life in testicular cancer survivors. Med Oncol [Internet] 2014;31(7):43. 9

23. del Giorno C, da Fonseca AM, Bagnoli VR, de Assis JS, Soares JM, Baracat EC. Effects of Trifolium pratense on the climacteric and sexual symptoms in postmenopause women. Rev Assoc Med Bras 2010;56(5):558-62.

24. Jessica L. Chan a, b, Joseph Letourneau a, c, WaelSalema, Aylin Pelin Cil a, d, SaiWing Chan a, Lee-may Chen a MPR a. Sexual satisfaction and quality of life in survivors of localized cervical and ovarian cancers following fertility-sparing surgery. Gynecol Oncol 2015;139(1):141-7.

25. Tucker PE, Bulsara MK, Salfinger SG, Tan JJS, Green $\mathrm{H}$, Cohen PA. Prevalence of sexual dysfunction after risk-reducing salpingo-oophorectomy. Gynecol Oncol 2016;

26. Tierney DK. Sexuality: A Quality-of-Life Issue for Cancer Survivors. Semin Oncol Nurs 2008;24(2):719.

27. Anna O. Levin, MA*, Kristen M. Carpenter, $\mathrm{PhD}^{*}$, Jeffrey M. Fowler, MD $\uparrow, \uparrow \mathrm{BM}$, Brothers, PhD Barbara L. Andersen, $\mathrm{PhD}^{*},+$, and G. Larry Maxwell M. Sexual morbidity associated with poorer psychological adjustment among gynecological cancer survivors. Int J Gynecol Cancer 2010;20(3).

28. Kim SI, Lee Y, Lim MC, et al. Quality of life and sexuality comparison between sexually active ovarian cancer survivors and healthy women. J Gynecol Oncol 2015;26(2):148-54.

29. Linden W, Vodermaier A, MacKenzie R, Greig D. Anxiety and depression after cancer diagnosis: 
Prevalence rates by cancer type, gender, and age. J Affect Disord [Internet] 2012;141(2-3):343-51. Available from: http://dx.doi.org/10.1016/j.jad.2012.03.025

30. Watts S, Prescott P, Mason J, Mcleod N, Lewith G. Depression and anxiety in ovarian cancer: a systematic review and meta-analysis of prevalence rates. BMJ [Internet] 2015;30:(5(11)). Available from: http://dx.doi.org/10.1136/

31. Nazik E, Arslan S, Nazik H, Narin MA, Karlangic H, Koc Z. Anxiety and symptom assessment in turkish gynecologic cancer patients receiving chemotherapy. Asian Pacific J Cancer Prev 2012;13(7):3129-33.

32. Chittrakul S, Charoenkwan K, Wongpakaran N. Prevalence of Anxiety May Not be Elevated in Thai Ovarian Cancer Patients Following Treatment. Asian Pac J Cancer Prev 2015;16(June 2013):2013-6. 10

33. Roland KB, Rodriguez JL, Patterson JR, Trivers KF. A literature review of the social and psychological needs of ovarian cancer survivors. Psychooncology 2013;22(11):2408-18. 